\title{
Further Glimpse at Intonation Teaching
}

\author{
Luu Trong Tuan \\ Ho Chi Minh City University for Natural Resources and Environment, Vietnam \\ E-mail: luutrongtuan@vnn.vn
}

Received: June 7, 2011 Accepted: June 29, $2011 \quad$ Published: January 1, 2012

doi:10.5539/ass.v8n1p224

URL: http://dx.doi.org/10.5539/ass.v8n1p224

\begin{abstract}
This paper sought to find out why intonation has been neglected in the process of teaching pronunciation to EFL learners at Ho Chi Minh City University for Natural Resources and Environment (HCMUNRE) and corroborate that teaching intonation in Yes/No questions and Wh-questions to learners has positive influence on their English speaking skill. The research also suggested some useful in-class activities to teach intonation in Yes/No questions and Wh-questions to EFL learners.
\end{abstract}

Keywords: Intonation, Pronunciation, Speaking skill, English as a Foreign Language (EFL)

\section{Introduction}

Zerbian's (2010) study describes recent developments in the study of intonation as they contribute to the goal of an intonational typology. Intonation has been invoked in theories of turn taking and speaker commitment (Gunlogson, 2003; Haan, 2002; Steedman, 2000). Recent work has posited various roles for intonation in the interpretation of biased questions from the semantic point of view (Romero, 2006; Reese, 2007). Intonation is crucial for learners of English as a Foreign Language (EFL), especially for those whose native language does not have a similar intonation system as English. It is widely known that "English is an intonation language" (Roach, 1991) while "Vietnamese is a tone language" (Avery and Ehrlich, 1992, p. 77). A challenge is found in the research of intonation in a (fully) tonal language (Hyman and Monaka, 2011).

Despite its magnitude, intonation has never been integrated into any English course at Ho Chi Minh City University for Natural Resources and Environment (HCMUNRE), either compulsory or optional, even though the knowledge of intonation can help the students improve their speaking skill. If HCMUNRE's students are to achieve fluency and comprehensibility in communication in English, an integrated course covering the four basic language skills, including intonation in Yes/No questions and Wh-questions, is undoubtedly and urgently needed. This study is guided by the ensuing research questions:

1) Why has intonation been neglected in the process of teaching pronunciation to EFL students at HCMUNRE?

2) How does teaching intonation in Wh-questions and Yes/No questions improve the students' speaking skill?

3) What are some activities that can effectively teach the intonation of Wh-questions and Yes/No questions in class to EFL students at HCMUNRE?

\section{Literature review}

This section presents depictions of intonation, the framework of English intonation, intonation patterns of questions, and the magnitude of teaching intonation in Yes/No questions and Wh -questions.

\subsection{Depictions of intonation}

\subsubsection{Concepts of intonation}

O'Connor (1980, p. 108) stated that "every language has melody in it; no language is spoken on the same musical note all the time". He also confirmed the importance role of intonation in languages:

The voice goes up and down and the different notes of the voice combine to make intonation. Generally, intonation plays an important part in languages. For example, in some languages such as Chinese languages, many languages in south-east Asia, Africa and America, intonation belongs to the word. The 
same sounds said with different intonation patterns may make quite different words. However, in English and many other languages, intonation belongs to the word group. We can say a word group definitely, hesitantly, angrily or kindly, with interest or without interest, and these differences are largely made by intonation we use: the words do not change their meaning, but intonation we use adds something to the words, and what it adds is the speaker's feelings at that moment.

Some people think that intonation is the same for all languages, but it is not true. English intonation is English: it is not the same as the intonation of other languages (O'Connor, 1980, p. 108). Celce-Murcia and Olshtain (2000, p. 33) said that most of the world's languages can be classified as either tonal languages or intonation languages, of which English is intonation language. In tonal languages, pitch applies lexically to distinguish words; on the contrary, in intonation languages, pitch patterns are applied to entire utterances.

Intonation has been defined by many linguists. Cruttenden (1986, p. 9), for instance, appears to equate intonation specifically with pitch movement, while Coulthard (1992, p. 96) has identified it with prosody in general, which would therefore, not only include pitch movement but also loudness, length, speed, and even voice quality. Pitch, however, is the common thread running through most descriptions. Intonation, then, can be narrowly described as "the movements or variations in pitch to which we are attached familiar labels describing levels (e.g. high-low) and tones (e.g. falling-rising), etc." (Higuchi, 2002, p. 1). Or it can be broadly defined as "systematic variations in pitch level, pitch movement and prominence." (Higuchi, 2002, p. 1). In the same vein, Gussenhoven (2006, p. 1) refers to intonation as "the structured variation in pitch which is not determined by lexical distinctions as in tone languages." Grice (2006), on the other hand, argues in favour of a broader definition of intonation, which goes beyond the mere pitch movements of an utterance:

"However, this distinction between prosody and intonation is rather artificial, since the terms are often used interchangeably -not only in more traditional phonetic models such as the British School (Crystal, 1969; Cruttenden, 1997), but also within phonological models of intonation which embrace the autosegmentalmetrical framework. In this account, we use the term intonation, in its broad sense, to cover both aspects." (p. 778)

Another definition about intonation given by Bradford (1988, pp. 1-2) is that intonation is a "feature of spoken language. It consists of the continuous changing of the pitch of a speaker's voice to express meanings". People can mean different things by using the same group of words, arranged in the same order, by saying them in different ways. A speaker is able to make a group of words mean what he/she wants it to by choosing the right intonation. Without intonation, it's impossible to understand the expressions and thoughts that go with words.

\subsubsection{Functions of intonation}

According to Gussenhoven $(2004$, p. 50$)$, “...people use it (intonation) to express their feelings; it encodes information structure of the sentence; it appears sensitive to syntactic categories like 'argument' and 'predicate'; it appears to have different phonetic forms in different segmental conditions; it is integrated with lexical tone distinctions in tone languages...". Kenworthy (1987, pp. 88-90) proposed eight functions of intonation:

(1) Foregrounding. Intonation is used to put words in the foreground.

(2) Backgrounding. Just as high pitch or drastically changing pitch is used to show prominence, low pitch is used to put things in the background, to treat something as old or shared information.

(3) Intonation is used to signal ends and beginnings.

(4) Intonation is used to show whether a situation is basically 'open' or 'closed'.

(5) Intonation is used to show involvement.

(6) Intonation is used to show expectations.

(7) Intonation is used to show that one speaker respects or cares about the other (especially as regards his or her status or feelings).

(8) Intonation is used to show the relationship between the parts of a speaker's message.

\subsubsection{Stress-timed language vs. syllable-timed language}

Avery and Ehrlich (1992, p. 73) claimed that "English is a stress-timed language" which the length of a sentence is affected by the amount of stressed syllables. Meanwhile, in syllable-timed language, the length of an utterance is determined the number of syllables. Therefore, it is difficult for learners whose native language is syllable-timed language because they usually give equal stress to every syllable in an utterance and this may lead to incomprehensibility of their English. 


\subsection{The framework of English intonation}

For Cruttenden (1986, p. 35), intonation has three important features (1) division of a stream of speech into intonation units (2) selection of a syllable (of a word), which is assigned the tonic status, and (3) selection of a tone for the intonation unit. Brazil et al. (1980) added another feature to the list, the pitch range, or key. It was also proposed that a framework of English intonation should include four major intonational features: intonation unit, stress, tones, and pitch range (Celik, 2001).

\subsubsection{Intonation unit (tone group)}

An "intonation unit" has been defined by many linguists and scholars. Halliday (1970, p. 40) stated that "The tone group is a unit of information. The speaker decides how he wants to break up the message-unconsciously, of course - into blocks or units of information, and each of these is expressed as one tone group". According to Celce-Muria et al. (1996, p. 175), intonation units describe the semantically and grammatically coherent segments of speech, and that every unit of speech has its own intonation contour or pitch pattern and typically contains one prominent element. A single utterance or sentence may include several intonation units. Additionally, Halliday (1970, p. 3) stated that the intonation unit in English is also called the tone group. Celce-Murcia et al. (1996, p. 175) summarized the characteristics of a typical intonation unit:

(1) is set off by pauses before and after

(2) contains one prominent element

(3) has an intonation contour of its own

(4) has a grammatically coherent internal structure

In many cases, in conversational English, intonation units correspond most frequently with grammatical clauses, but it is not the case that every clause is one tone group because the tone group is a meaningful unit in its own right. From Halliday's (1970, p. 3) standpoint, a tone group is one information unit, one 'block' in the message that the speaker is communicating; and so it can be any length, for example, in rapid speech, intonation units may be fairly long and in slower speech, they may be shorter. Additionally, Halliday (1970, p. 40) asserted that "Information units are not the same as sentences or clauses or phrases, but represent a different kind of organization that exists side by side with structure of sentences". However, pausing may bring about a change of meaning; certain pauses in a stream of speech can have significant variations in the message to be conveyed. Furthermore, Halliday (1970, pp. 3-4) stated that in reading aloud, or in more formal speech, clauses tend to be divided into quite a number of tone groups, because they are rather long and full of information, and the speakers are active in deciding how to segment the information. Similarly, Celce-Murcia et al. (1996, p. 176) said that "where the utterance divisions fall will also depend on the individual speaker", or in other words, such divisions are dependent on the performance context. Celce-Murcia et al. (1996) explained that "public speakers tend to pause frequently to make their messages clearer or more emphatic (p. 176). On the contrary, the intonation unit may be longer if the speaker is in an emergency situation. Halliday (1967, p. 200) said that the speaker is free to decide how he wishes to package the information, where each information unit begins and ends, and how it is organized internally.

Brown and Yule (1983, p. 155) said that the 'internal organization' of the information unit relates to the way in which given and new information is distributed within the unit. Characteristically, Halliday (1970, pp. 40-41) suggested that the speaker will order given information before new information. The 'unmarked' sequencing of information structure is taken to be given-new. Normally, information units which are initial in a discourse will contain only new information. In addition, Brown and Yule (1983, p. 177) explained that given and new information in sentences is signaled by stress or accent on particular words. However, not all linguists agreed that it is a straightforward matter to isolate tone groups. Evidence shows that even trained native speakers find it difficult to break talk up into such units and to identify tonics in speech (Brown and Yule 1983, p. 158).

\subsubsection{Stress}

\subsubsection{Word stress}

According to Celce-Murcia et al. (1996, p. 131), syllables in utterances which are longer, louder, and higher in pitch are called stress syllables and Avery and Ehrlich (1992, p. 63) stated that stress vowels are longer and louder vowels. Meanwhile, stress has been defined as the degree of force by Jones (1998, p. 141) that a speaker makes when he pronounces a sound or a syllable. Moreover, Kelly (2000, p. 66) said that "each stressed syllable, in a word in isolation, also has a change in the pitch, or the level of the speaker's voice, and the vowel sound in that syllable is lengthened". 
According to Celce-Murcia et al. (1996, p. 132), English language-teaching texts generally speak of three levels of word stress, or the pattern of stressed and unstressed syllables within one word. These levels are often referred to as strong, medial, and weak (or alternatively, primary, secondary, and tertiary). For pedagogical purposes, these levels are called strongly stressed, lightly stressed, and unstressed syllables. However, Kelly (2000, p. 69) argued that within longer words syllables can have different degrees of stress. While some commentators have outlined up to five different levels of stress in a single word, most commentators settle on a three-level distinction of primary stress, secondary stress and unstressed. However, in practical terms a two-level division (stressed and unstressed) is usually adequate for teaching purposes. Characteristically, Gussenhoven (2004, p. 20) summarized 'degrees' of stress as follows:

$<$ Insert Table 1 here $>$

According to Avery and Ehrlich (1992, p. 67) and Kelly (2000, p. 68), there are no hard and fast rules for word stress. Factors that influence stress placement include the historical origin of a word, affixation, and the word's grammatical function in an utterance (Celce-Murcia et al., 1996, p. 133).

\subsubsection{Sentence stress}

The use of stress in speech helps learners to both deliver and understand meaning in longer utterances and Kelly $(2000$, p. 71$)$ said that it is closely linked with intonation. At the clausal level, words that carry higher information content in the utterance are normally given higher stress than those carrying lower input and those that are predictable in the context. Words that carry higher information content are called 'content' words, as opposed to 'function' words - which are used in order to make the sentences grammatically correct. According to Jones $(1998$, p. 145), the stressings of words in sentences vary according to the degrees of emphasis one wishes to give to particular words. Kelly $(2000$, p. 72) and Celik (2001) had the same opinion about the classification between content words and functions. They said that this classification conforms to grammatical consideration. The following table categorizes content words and function words, and illustrates which words in a sentence or utterance tend to receive stress and which do not.

$<$ Insert Table 2 here $>$

It is necessary to remember that these basic rules are only suitable for starters. In everyday speech, stress depends on the speaker's feeling/attitude, the context, the information that the speaker wants to share with the hearer. Therefore, four major types of stress in sentence have been identified:

(1) unmarked tonic stress

(2) emphatic stress

(3) contrastive stress

(4) new information stress

An intonation unit almost always has one peak of stress, which is called 'tonic stress' or 'nucleus'. Because stress is applied to syllables, the syllable that receives the tonic stress is called the 'tonic syllable'- it is generally longer, louder, and carries the main pitch movement in an utterance. Tonic stress is almost always found in a content word in the final position of an utterance.

Emphatic stress is used when the speaker wishes to place special emphasis on a particular element (Celce-Murcia et al., 1996, p. 177). In fact, the element receiving emphatic stress usually communicates new information within the sentence.

According to Avery and Ehrlich (1992: 189), the last content word of a sentence usually receives major sentence stress (also called tonic stress). However, they also said that not every last content word is the main information the speaker wants to emphasize.

In contrastive contexts, the stress pattern is quite different from the emphatic and non-emphatic stresses in that any lexical item in an utterance can receive the tonic stress (also called major sentence stress) provided that the contrastively stressed item can be contrastable in that universe of speech. No distinction exists between content and function words regarding this. The contrasted item receives the tonic stress provided that it is contrastive with some lexical elements in the stimulus utterance. Syllables that are normally stressed in the utterance almost always get the same treatment they do in non-emphatic contexts.

Within an intonation unit, words spoken with strong stressed and higher pitch are new information (Celce-Murcia et al., 1996, p. 176). According to Celik (2001), the concept of new information is much clearer to students of English in responses to Wh-questions than in declarative statements. 


\subsubsection{Tones}

There are different numbers of tones in different books about English intonation because the authors have their own ways to explain and teach language (Halliday, 1970, p. 8). Pointing to extensive variation in the taxonomy of English tones, Cruttenden (1986, p. 58) notes that "this is an area where almost every analyst varies in his judgment of what constitutes a major different of meaning and hence in the number of nuclear tones which are set up". Crystal (1969) and Ladefoged (1982) identified four basic tones (fall, rise-fall, rise, and fall-rise) while O'Connor and Arnold (1973) distinguished only two (rise and fall). Brazil (1997: 67), Roach (1983) and Mc Carthy (1991: 105) endorsed five tones (fall, rise, rise-fall, fall-rise, and level). Similarly, Halliday (1970, p. 9) suggested five simple tones (falling, high rising/falling-rising, low rising, falling-rising, rising-falling) and two compound tones (falling plus low rising, rising-falling plus low rising) whereas Cruttenden (1986) recognized seven tones (high-fall, low-fall, high-rise, low-rise, fall-rise, rise-fall, and mid-level).

Nevertheless, the core of this research is applying intonation in Yes/No questions and Wh-questions, therefore, this research focuses on studying tones applied to questions. According to Brazil (1997, pp. 99-113), proclaiming tone (fall-p or rise-fall-p+) and the referring tone (rise-r or fall-rise-r+) convey different meanings when applied in different kinds of questions. First, in declarative mood questions, referring tone means common ground shared between the speakers.

\subsection{Intonation patterns of questions}

Intonation doesn't exist in isolation. So it makes sense to approach it along with factors such as grammar, the speaker's emotions, feelings, or attitudes. Here, the relationship between intonation and grammar is initially discussed.

According to Celce-Murcia et al. (1996, p. 201), rising intonation is used in unmarked Yes/No questions. In addition, Halliday $(1970$, p. 23) pointed out that rising tone is used in Yes/No questions where the speaker is sure that he does not know the answer, and that addressee knows the answer. Celce-Murcia et al (1996, p. 201) also added that "Since the intonation can rise on whichever constituent is in focus, this intonation pattern often has two or three possible contours depending on the syntactic complexity and length of the question". A statement pronounced with rising tone is considered as an uninverted question (Celce-Murcia et al., 1996, p. 202). This kind of Yes/No questions can take two different prosodic patterns. The first pattern has normal stress and rising intonation, however, it has several possible contours because of the difference on primary stress and rise on constituents in focus.

Halliday (1970, p. 23) stated that falling tone is used in Wh-questions. Similarly, Brazil (1997, p. 110) also proposed that falling tone occurs in this type of question as the longstanding tradition. However, according to Celce-Murcia et al. (1996, p. 204), "Wh-questions follow the same rising-falling intonation as statements when they are unmarked, with the rise corresponding to the most prominent element in the utterance". They also added that "Often with Wh-questions, there are two or more different contours depending on whether the result of the action or the agent of the action is in focus". In addition, Celce-Murcia et al. (1996, pp. 185-186) also gave an indepth explanation about this type of intonation "Rising-falling intonation patterns of the 2-3-1 'certain' type (i.e., the utterance begins at level 2 , rises to level 3 , and then falls to level 1 ) typically signal the following types of utterances: declarative statements, Wh-questions, and commands or directives".

\subsection{The magnitude of teaching intonation in the process of teaching language skills based on communicative} approach

Avery and Ehrlich (1992, p. 192) stated that "intonation is not only central to conveying meaning in spoken English but is also important in conveying the attitude of the speaker towards what is being said". A simple word such as $\mathrm{Oh}$ spoken with different intonation contours can express meanings which range from complicity to shock and disbelief, from surprise to disappointment, from 'I didn't know that' to frustration. Additionally, Halliday (1970, p. 21) considered intonation as a means to say different things. The meaning of a sentence is changed if the speaker changes its intonation. Similarly, Celce-Murcia and Olshtain (2000, p. 35) claimed that "Without sounds system there would be no spoken language and no oral communication..."

According to Kelly (2000, pp. 86-87), the teacher needs to show learners how the choices they make with regard to intonation serve to determine the meaning of utterances. As well as helping to determine meaning, intonation gives the learners clues about the attitude or the feeling of the speaker toward what he or she is saying. When listening to people speaking, the listeners can get clear messages about the speakers' attitude from the intonation patterns being used. 
Learners have difficulty in speaking English fluently because they usually concentrate so much on finding the right words and grammar that intonation suffers, yet intonation can be as important as word choice and grammar structure. It is possible to say that intonation facilitates speaking skills because incorrect intonation can result in misunderstandings, listeners losing interest, or even break downs in communication.

\section{Methodology}

\subsection{Participants}

\subsubsection{The student sample}

The subjects were from two classes (Environmental Science and Land Management) at HCMUNRE. Although they studied different majors, students in both classes were all freshmen. The number of students responding to the survey was 56; this was out of a total number of 62 students, since six students were absent from school. The predominant gender of the two groups was female $(61,5 \%$ in the Environmental Science class and $87 \%$ in the Land Management class). The Environmental Science class was randomly selected as the experimental group and the Land Management class was the control group. The age of the subjects in the two groups ranged from 19 years old to 28 years old, of which the most common age was 20 (38\% in the experimental group and $57 \%$ in the control group). The age that students started learning English also varied from 6 years old to 23 years old. This difference was due to the fact that some of the subjects started learning English at a very early age (six years old); while others started later, such as one student who started learning English when he studied at university (twenty three years old). The most common age when the students in the two groups started learning English was twelve ( $46 \%$ in the experimental group and $77 \%$ in the control group). Therefore, the students were expected to have the basic knowledge needed to understand the concepts, terms and rules related to intonation in Yes/No questions and Wh-questions during the process of experimental teaching.

\subsubsection{The teacher sample}

The teacher subjects included three sub-groups, with the researcher also playing the role of a teacher during the experimental teaching process. Two foreign teachers listened to recordings of the students' responses and evaluated the students' intonation in Yes/No questions and Wh-questions to express meanings during the pre-test and post-test using evaluation sheets designed by the researcher, in order to determine if there was any difference before and after teaching. Fifteen Vietnamese teachers at HCMUNRE were provided with the teachers' questionnaire and asked to give reasons for the neglect of teaching intonation in the process of teaching pronunciation as well as to express their attitudes and thoughts about teaching intonation in Yes/No questions and Wh-questions and/or to provide some useful activities of teaching intonation in Yes/No questions and Whquestions. Twelve responses were returned.

\subsection{Instruments}

\subsubsection{Student questionnaire}

The student questionnaire involved seven questions focusing on students' attitudes toward learning intonation in Yes/No questions and Wh- questions. The questionnaire was given to students in their classrooms during the first day of the course, at the beginning of January in the school year 2010-2011. The researcher carefully instructed students on how to answer all the questions and clearly explained the purpose of the questionnaire. The questionnaire was collected on the same day.

\subsubsection{Teacher questionnaire}

The teacher questionnaire comprised four questions investigating teachers' attitudes and experience in teaching intonation and some useful techniques / activities in teaching intonation in Yes/No questions and Wh-questions to non-English major students in class. The questionnaire was provided to the teachers at HCMUNRE. The majority of the subjects were part-time teachers and the total number of teachers at HCMUNRE varies throughout the academic year. In the first semester of that school year, there were 24 teachers. However, 15 teachers were randomly selected to give answers to the questionnaire.

\subsubsection{Tests}

Two tests - a diagnostic test (or pretest) and an achievement test (or posttest) - were designed by the researcher and shared the same format, but contained different questions to assess students' capabilities. Each test included two parts, a reading part and a speaking part, in which the reading part consisted of three sections. Students were required to use intonation and stress to highlight their ideas while they were reading the two conversations in section 1. In section 2, students were asked to choose one suitable question among three for the given answer in each conversation, before they read the two conversations. Students also read the conversation in section 3, using 
intonation to express their attitudes and ideas. Another part was the speaking part, in which students were required to play all the roles in the conversation.

\subsection{Data collection procedures}

The students' questionnaire was handed to the subjects of the two classes in their classrooms by the researcher on the first class meeting and collected on the same day. The teachers' questionnaire was collected during one week. The results of the teachers' and students' questionnaires were then categorized and analyzed to find out the reasons why intonation has been rarely taught at HCMUNRE and to examine the teachers' and students' attitudes and experiences toward teaching intonation in Yes/No questions and Wh-questions to non-English major students as well as to elicit techniques/activities in teaching intonation in Yes/No questions and Wh-questions in class.

The first class meeting was also the day when students of the two classes took the diagnostic test. The students were guaranteed that the scores of the diagnostic test would not affect their results for their main courses. Then the students' responses were evaluated by two foreign teachers and the results were used to design suitable classroom activities for lesson plans for the experimental class.

After the eight-week experimental teaching, the achievement test was recorded by the researcher on different days, depending on the group's schedule. Specifically, the control group took the achievement test on 27 April 2011 and the experimental group sat the achievement test on 29 April 2011. The CDs were listened to and evaluated by the same two foreign teachers. The results of the achievement test were analyzed and compared with the results from the diagnostic test to determine the effectiveness of teaching intonation in Yes/No-questions and Wh-questions on students' speaking skills.

\section{Data analysis}

\subsection{Findings from the student questionnaire survey}

The data in this section are presented in the same order as the dimensions in the questionnaire. The first dimension encompassing question 1 through 7 aimed at collecting information about the students' attitudes toward learning intonation in class.

Question 1 asked the students about the frequency of learning intonation in Yes/No questions and Wh-questions in class. The majority of the students (48.2\%) asserted that intonation in Yes/No questions and Wh-questions has been seldom taught in class, $37.5 \%$ chose not very often, whereas only one (1.8\%) out of 56 students learned it very often, and $9 \%$ ticked often. It can be concluded from the data that teaching intonation has been neglected at HCMUNRE.

Question 2 asked the students to express their own opinions about how English intonation in Yes/No questions and Wh-questions affects their speaking skills. Interestingly, $69.6 \%$ strongly agreed and $21.4 \%$ agreed that studying intonation can improve their speaking skills. While, only two students (3.6\%) disagreed and three respondents $(5.4 \%)$ left it unanswered. This can be interpreted as most of the students strongly agreed with the important impact of intonation on their speaking skills.

Question 3 aimed at finding out the students' opinions on how intonation can improve their speaking skills. Since this question was optional (Note 1), $91 \%$ of $100 \%$ gave responses and students could choose more than one answer for this question. Half of the students $(50 \%)$ said that learning intonation can help them speak English more fluently, $37.5 \%$ believed that they can speak English faster through learning intonation. Interestingly, $86 \%$ chose the option of pronounce correctly to this question. These figures show that students are aware of which aspects of speaking skills intonation can improve.

Question 4 surveyed the students' opinion about the important role of intonation in studying English. Out of the 56 respondents participated in the survey, only one student $(1.8 \%)$ denied the important role of intonation in studying English. Forty-four (78.5\%) out of 56 respondents strongly agreed with the important role of intonation, and $10(17.9 \%)$ chose the option of agree with this question. The results of this questions showed that the student subjects highly appreciate the role of intonation in studying English.

Question 5 asked for the students' interest toward learning intonation. Out of the 56 respondents involved in the study, 22 students $(39 \%)$ said that studying intonation is very interesting and $24(46.4 \%)$ chose interesting. Only $3.6 \%$ ticked boring for their option, 5.4\% had no idea about this question and 5.4\% left the answer blank for this option. It can be interpreted that the majority of student subjects really enjoyed learning intonation. 
Question 6 requested the students to give reasons behind their interest in studying intonation in Yes/No questions and Wh-questions, however, not all students gave responses to this question because it was optional (Note 2). This question required open answers from the respondents. Here are some answers:

Because studying intonation in Yes/No questions and Wh-questions are funny and intonation can help me speak English fluently.

Because I want to speak English fast and pronounce correctly.

Amazingly, it (intonation) helps me confident.

Because it helps students feel more enjoyable in studying English.

Because it is easy to study.

Because I have never studied intonation before.

The above opinions highlight the fact that students feel that studying intonation in Yes/No questions and Wh-questions is needed at HCMUNRE because it facilitates the improvement of the students' speaking skill.

The purpose of question 7 was to investigate the reasons why studying intonation is boring. It was also an optional question (Note 3); however, only two students stated that studying intonation in Yes/No questions and Wh-questions was boring. Hence, only one reason was presented "I don't study English very well". From such a reason, it can be assumed that this student does not have enough basic knowledge to understand the terms and concepts related to intonation.

The second dimension aimed at finding out how much the student subjects know about intonation in Yes/No questions and Wh-questions. The respondents were asked to choose the tones for isolated questions. Students' choices are summarized in the Tables $3 \& 4$.

$<$ Insert Table 3 here $>$

As can be seen from Table 3, 17 (30.3\%) selected rising tone for question 1, and 19 (34\%) employed falling-rising tone for this question; only four respondents $(7.1 \%)$ chose falling tone and $13(23.2 \%)$ wrote rising-falling tone for this question. Unexpectedly, only 4 (7.1\%) out of 56 respondents used rising tone, and 18 (32\%) employed falling-rising tone for question 2. Surprisingly, 27 (48.2\%) chose falling-rising for question 4, and 11 students (19.6\%) stated that rising tone is used for this question. From these figures, it can be interpreted that the concept of intonation in Yes/No questions and Wh-questions is vague to the student subjects.

As regards Wh-questions (see sentences 3, 5, 6 in Table 4), not many students chose falling tone for this question type. Interestingly, it was significantly different from rising-falling intonation as $27(48.2 \%)$ and $24(43 \%)$ used rising-falling tone for questions 3 and 6. Disappointingly, 24 (43\%) respondents selected rising tone and 13 $(23.2 \%)$ employed falling-rising tone for question 5. Once again, it can be concluded that the student subjects do not have basic knowledge about intonation in Yes/No questions and Wh-questions.

$<$ Insert Table 4 here $>$

\subsection{Findings from the teacher questionnaire survey}

The results of this questionnaire are presented according to order of the dimensions in the questionnaire.

The first dimension surveyed the teachers' attitudes toward teaching intonation in Yes/No questions and Wh-questions, as well as activities applied in teaching intonation in Yes/No questions and Wh-questions. The teachers were also requested to reveal their opinion about the magnitude of intonation teaching to EFL students at HCMUNRE.

As regards question 1 of the first dimension, 33.3\% respondents agreed and 58.3\% strongly agreed that teaching intonation in Yes/No questions and Wh-questions to non-English major students is necessary. Only one (8.3\%) had no opinion for this question.

In question 2 of the first dimension, the teachers were asked to express their opinions about the role of intonation in communication. Out of the 12 teachers who participated in the survey, seven respondents (58.3\%) agreed and $25 \%$ strongly agreed that English intonation plays an important role in communicative competence. Only one teacher $(8.3 \%)$ out of the 12 respondents disagreed with this idea and one teacher $(8.3 \%)$ was not sure about this option.

Question 3 of the first dimension surveyed the teachers' viewpoint about the importance of intonation in Yes/No questions and Wh-questions in improving their students' speaking skill. $25 \%$ of the teacher subjects strongly agreed and $42 \%$ of the teachers agreed that learning intonation in Yes/No questions and Wh-questions can 
improve the students' speaking skills. Unexpectedly, $33 \%$ of the teachers were not sure about this option. However, the results of this question showed that over a half of the teacher subjects $(66 \%)$ recognized the important role of intonation in Yes/No questions and Wh-questions in improving the students' speaking skill.

Question 4 of the first dimension asked about the teachers' techniques and/or activities applied in teaching intonation in Yes/No questions and Wh-questions in class. The followings are techniques and/or activities were collected from the teacher subjects:

a) Yes/No questions

- Listen and repeat.

- Practice in pairs.

- Use communication games (Find someone who..)

- Model the language.

- Listen to the tape.

b) Wh-questions

- Drill.

- Use face- to-face conversations.

- Work in pairs.

- $\quad$ Listen to the tape.

- Listen and repeat.

- Use games.

- Model the language.

- Use task based activities.

- Use situation based activities.

The second dimension in the questionnaire aimed at finding out why intonation has been neglected in the process of teaching at HCMUNRE.

Question 1 of the second dimension asked the teacher subjects whether they often teach intonation in Yes/No questions and Wh-questions in class at HCMUNRE or not. The majority of the teacher subjects (83\%) do not often teach intonation in Yes/No questions and Wh-questions in class at HCMUNRE. From such findings, it can be stated that intonation has been rarely taught at HCMUNRE although most of the teacher subjects recognized the important impact of intonation on students' speaking skill.

Question 2 of the second dimension was an optional question (Note 4), hence, not all of the respondents gave responses to this question. The following reasons were collected from the teachers about the neglect of teaching intonation at HCMUNRE:

- Not many course books have this part. (2 teachers)

- $\quad$ There is less natural practice from students. (1 teacher)

- We do not have enough time in class.(4 teachers)

- There are not many activities to make the classroom interesting. (1 teacher)

- Teaching intonation should not be separated from the other macro skills. (1 teacher)

- It is time-consuming. (1teacher)

Question 3 of the second dimension was also an optional question (Note 5). As mentioned in the results of question 1, two teachers ticked Yes for this question, therefore, there were also two teachers who gave responses to this question and both of them said that "They usually spend five minutes on teaching intonation in Yes/No questions and Wh-questions in class in each period." The results collected from this question lead to the conclusion that teaching intonation in Yes/No questions and Wh-questions have been rarely taught in classes at HCMUNRE.

\subsection{Findings from the posttest scores}

As displayed in Table $5 \mathrm{~b}$ of independent samples test, Levene's test was used to test the null hypothesis that there is no significant difference in the variances of the two groups. As the "Sig." value is 0.452 which is greater 
than the $p$ level (.05), this null hypothesis is accepted, and it can be concluded that the homogeneity of variance assumption between the two groups is met. As a consequence, the row headed "Equal variances assumed" in Table $5 \mathrm{~b}$ was examined. The $t$-test for equality of means produced a $t$ value that equaled 1.645 , with degree of freedom (df) equal to 109 . The two-tailed probability is 0.013 ; since this level of significance is less than 0.05 , the two-tailed hypothesis is accepted, and the null rejected. In other words, there is a difference of students' pronunciation between the two groups. Therefore, the group statistics in Table 5a should be considered. The mean score of the experimental group is 7.8125 and the control group 7.2682 respectively, which implies that the students in the experimental group exhibited better pronunciation performance than those in the control group in the posttest.

$<$ Insert Table $5 \mathrm{a}$ and Table $5 \mathrm{~b}$ here $>$

\section{Concluding thoughts}

From the responses of the two questionnaires, it can be seen that the majority of the students $(78.5 \%)$ and the teachers $(83.3 \%)$ recognized the magnitude of intonation in communication. On the other hand, also from the results of the questionnaires up to $85.7 \%$ of the students at HCMUNRE and $83 \%$ of the teachers admitted that intonation has not been taught regularly due to the reasons that follow. Firstly, the teachers usually spend most of their time on teaching compulsory lessons in the syllabus so there is no time to teach intonation. Secondly, they have no motivation to learn and teach intonation because it is not included in final exam. Finally, according to teachers' opinion at HCMUNRE, there are not many interesting activities to teach intonation in class.

\section{References}

Avery, P. \& Ehrlich, S. (1992). Teaching American English Pronunciation. Oxford: Oxford University Press.

Bradford, B. (1988). Intonation in Context: Student's Book. Cambridge: Cambridge University Press.

Brazil, D. (1997). The communicative value of intonation in English. Cambridge: Cambridge University Press.

Brazil, D., Coulthart, M. and Johns, C. (1980). Discourse Intonation and Language Teaching. Harlow (Essex): Longman.

Brown, G. \& Yule, G. (1983). Discourse Analysis. Cambridge: Cambridge University Press.

Celce-Murcia, M., Brinton, D. \& Goodwin, J. (1996). Teaching pronunciation. Cambridge: Cambridge University Press.

Celce-Murcia, M. \& Olshtain, E. (2000). Disourse and Context in Language Teaching: A Guide for Language Teachers. Cambridge: Cambridge University Press.

Celik, M. (2001). Teaching English Intonation to EFL/ESL Students. The Internet TESL Journal, Vol. VII, No. 12. [Online] Available: http://iteslj.org/Techniques/Celik-Intonation.html (May 19, 2004)

Coulthard, M. (1992). An Introduction to Discourse Analysis, Second Edition. New York: Longman Inc.

Cruttenden, A. (1986/1997). Intonation. Cambridge: Cambridge University Press.

Crystal, D. (1969). Prosodic Systems and Intonation in English. Cambridge: Cambridge University Press.

Grice, Martine. (2006). Intonation. In Brown, Keith (ed.), Encyclopedia of Language and Linguistics, Vol. 5, Oxford: Elsevier, 2nd edition, 778-788.

Gunlogson, C. (2003). True to form: Rising and falling declaratives as questions in English. Routledge.

Gussenhoven, C. (2004). The phonology of tone and intonation. Cambridge: Cambridge University Press. http://dx.doi.org/10.1017/CBO9780511616983

Gussenhoven, C. (2006). The Phonology of Intonation. In Paul de Lacy [ed.] The Cambridge Handbook of Phonology. Cambridge University Press.

Halliday, M.A.K. (1967). Intonation and Grammar in British English. Mouton: The Hague.

Halliday, M.A.K. (1970). A course in spoken English: Intonation. Oxford: Oxford University Press.

Haan, J. (2002). Speaking of Questions: An Exploration of Dutch Question Intonation. PhD thesis, Utrecht: LOT Graduate School of Linguistics.

Higuchi, M. (2000). Teaching English Intonation with Discourse Approach. [Online] Available: http://bambi.u-shizuoka-ken.ac.jp (January 21, 2010) 
Hyman, L.M. and Monaka, K.C. (2011). Tonal and Non-Tonal Intonation in Shekgalagari. Studies in Natural Language and Linguistic Theory, 2011, Vol. 82, 267-289. http://dx.doi.org/10.1007/978-94-007-0137-3_12

Jones, D. (1998). The pronunciation of English. Cambridge: Cambridge University Press.

Kelly, G. (2000). How to teach Pronunciation. Cambridge: Cambridge University Press.

Kenworthy, J. (1987). Teaching English Pronunciation. London: Longman Publishing Group UK Limited.

Ladefoged, P. (1982). A course in phonetics (2 ${ }^{\text {nd }}$ ed.). New York: Harcourt Brace Jovanovich.

McCarthy, M. (1991). Discourse Analysis for Language Teachers. Great Britain: Cambridge University Press.

O’Connor, J.D. (1980). Better English Pronunciation (2 ${ }^{\text {nd }}$ ed.). Cambridge: Cambridge University Press.

O’Connor, J.D. \& Arnold, G.K. (1973). Intonation of Colloquial English. London: Longman.

Reese, B. (2007). Bias in Questions. PhD thesis, University of Texas at Austin.

Roach, P. (1983/1991). English Phonetics and Phonology: A Practical Coursebook. Cambridge: Cambridge University Press.

Romero, M. (2006). Biased Yes/No Questions: The Role of VERUM. Sprache und Daten-Verarbeitung, $30(1): 9$.

Steedman, M. (2000). Information Structure and the Syntax-Phonology Interface. Linguistic Inquiry, 31(4): 649-689. http://dx.doi.org/10.1162/002438900554505

Zerbian, S. (2010). Developments in the Study of Intonational Typology. Language and Linguistics Compass, Vol. 4, No. 9, pp. 874-889. http://dx.doi.org/10.1111/j.1749-818X.2010.00233.x

\section{Notes}

Note 1. If students choose "Disagree or Strongly disagree", they will not answer this question

Note 2. If students choose "Very interesting, interesting", they will answer this question.

Note 3. If students choose "Very boring, boring", they will answer this question.

Note 4. They answer this question when they choose "No" for question 1.

Note 5. They answer this question if they choose "Yes" for question 1.

Table 1. Degrees of stress

\begin{tabular}{|c|c|c|}
\hline Degrees of stress & Position in structure & Phonetic correlates and examples \\
\hline Unstressed & Weak syllable in a foot & $\begin{array}{l}\text { Qualitative and durational reduction, } \\
\text { steep spectral tilt e.g. po- and -to in potato. } \\
\text { Vowels without qualitative and durational }\end{array}$ \\
\hline Stressed unaccented & Strong syllable in a foot & $\begin{array}{l}\text { reduction. Less steep spectral tilt e.g. caul- } \\
\text { and flow- in cauliflower, in the utterance I } \\
\text { LIKE cauliflower. }\end{array}$ \\
\hline Accented & $\begin{array}{l}\text { Stressed syllable with an } \\
\text { intonational pitch accent }\end{array}$ & $\begin{array}{l}\text { Strong syllable in foot, and so like stressed, } \\
\text { but additionally with pitch configuration } \\
\text { heard as 'sentence accent' .e.g. caul- in the } \\
\text { utterance I like CAULiflower. }\end{array}$ \\
\hline
\end{tabular}

Table 2. Content words versus function words

\begin{tabular}{|c|c|}
\hline Content / Stressed Words & Function / Unstressed Words \\
\hline $\begin{array}{ll}- & \text { Verbs } \\
- & \text { Nouns } \\
- & \text { Adjectives } \\
- & \text { Adverbs/Adverbial particles } \\
- & \text { Question words } \\
- & \text { Prepositional adverbs } \\
- & \text { Negative contractions (can't, isn't) or } \\
- & \text { even the negative particle not. } \\
- & \text { Demonstrative pronouns ( this, that, } \\
& \text { these, those) } \\
- & \text { Possessive pronouns (mine, yours, etc.) }\end{array}$ & $\begin{array}{ll}- & \text { Modal auxiliaries } \\
- & \text { Articles } \\
- & \text { Conjunctions } \\
- & \text { Prepositions } \\
- & \text { Pronouns (Personal pronoun) } \\
- & \text { Indefinite adjectives (some, such, any) } \\
- & \text { Possessive adjectives }\end{array}$ \\
\hline
\end{tabular}


Table 3. Students' tone choices in Yes/No questions

\begin{tabular}{lccc}
\hline $\begin{array}{l}\text { Sentence numbers } \\
\text { Numbers of } \\
\text { students who chose }\end{array}$ & 1 & 2 & 4 \\
\hline Rising $(\boldsymbol{\lambda})$ & $17(30.3 \%)$ & $4(7.1 \%)$ & $11(19.6 \%)$ \\
Falling $(\boldsymbol{У})$ & $4(7.1 \%)$ & $10(18 \%)$ & $5(9 \%)$ \\
Falling-rising $(\boldsymbol{\searrow})$ & $19(34 \%)$ & $18(32 \%)$ & $27(48.2 \%)$ \\
Rising-falling $(\boldsymbol{\nearrow})$ & $13(23.2 \%)$ & $22(39.3 \%)$ & $11(19.6 \%)$ \\
No answer & $3(5.4 \%)$ & $2(3.6 \%)$ & $2(3.6 \%)$ \\
\hline
\end{tabular}

Table 4. Students' tone choices in wh-questions

\begin{tabular}{clll}
\hline $\begin{array}{l}\text { Sentence numbers } \\
\text { Numbers of } \\
\text { students who chose }\end{array}$ & \multicolumn{2}{c}{5} & \multicolumn{1}{c}{6} \\
\hline Rising $(\boldsymbol{\lambda})$ & $3(5.4 \%)$ & $24(43 \%)$ & $10(18 \%)$ \\
Falling (ע) & $6(10.7 \%)$ & $7(12.5 \%)$ & $4(7 \%)$ \\
Falling-rising $(\boldsymbol{y})$ & $19(34 \%)$ & $13(23.2 \%)$ & $17(30.3 \%)$ \\
Rising-falling $(\boldsymbol{ス})$ & $27(48.2 \%)$ & $11(19.6 \%)$ & $24(43 \%)$ \\
No answer & $1(1.7 \%)$ & $1(1.7 \%)$ & $2 \quad(1.7 \%)$ \\
\hline
\end{tabular}

Table 5a. Group Statistics

\begin{tabular}{llrrrr}
\hline \multicolumn{1}{c}{ Groups } & N & \multicolumn{1}{c}{ Mean } & Std. Deviation & \multicolumn{1}{c}{$\begin{array}{c}\text { Std. Error } \\
\text { Mean }\end{array}$} \\
\hline \multirow{2}{*}{ Posttest scores } & Experimental group & 56 & 7.8125 & 1.90350 & .25437 \\
& Control group & 55 & 7.2682 & 1.56188 & .21060 \\
\hline
\end{tabular}

Table 5b. Independent Samples Test

\begin{tabular}{|c|c|c|c|c|}
\hline & & & \multicolumn{2}{|c|}{ Posttest scores } \\
\hline & & & $\begin{array}{c}\text { Equal } \\
\text { variances } \\
\text { assumed }\end{array}$ & $\begin{array}{c}\text { Equal } \\
\text { variances not } \\
\text { assumed }\end{array}$ \\
\hline \multirow[t]{2}{*}{$\begin{array}{l}\text { Levene's Test for Equality } \\
\text { of Variances }\end{array}$} & $\mathrm{F}$ & & .569 & \\
\hline & Sig. & & .452 & \\
\hline \multirow[t]{7}{*}{$\begin{array}{l}\text { t-test for Equality of } \\
\text { Means }\end{array}$} & $\mathrm{t}$ & & 1.645 & 1.648 \\
\hline & $\mathrm{df}$ & & 109 & 105.674 \\
\hline & Sig. (2-tailed) & & .013 & .012 \\
\hline & Mean Difference & & .54432 & .54432 \\
\hline & Std. Error Difference & & .33082 & .33024 \\
\hline & $\begin{array}{l}95 \% \text { Confidence Interval of } \\
\text { the Difference }\end{array}$ & Lower & -.11136 & -.11043 \\
\hline & & Upper & 1.20000 & 1.19907 \\
\hline
\end{tabular}

